\title{
Evidence for Top Shuaiba Exposure and Incision in Block 5, Offshore Qatar, and Regional Consequences
}

M. Raven (Maersk Oil), F. van Buchem* (Maersk Oil Qatar), P.H. Larsen (Maersk Oil), F. Surlyk (University of Copenhagen), H. Steinhardt (Maersk Oil Qatar) \& M. Emang (Qatar Petroleum)

\section{SUMMARY}

An integrated subsurface data set of core, vertical and horizontal wells and seismic has provided evidence for the presence of karstification and quartz sand filled platform incision at the top of the Shuaiba Formation in offshore Qatar. These observations have significant implications for the late Aptian palaeogeography and related understanding of the distribution of late Aptian/early Albian siliciclastics in the region. In addition, it provides a Late Aptian reference curve for the Arabian plate. 


\section{Introduction}

Although there is a wealth of information available on the Lower Aptian stratigraphy in the Middle East, very little is as yet known about the Upper Aptian. During this time interval large parts of the eastern Arabian plate became exposed, affecting one of the most prolific carbonate reservoirs in the region (Shuaiba Formation), and sedimentation was limited to the remaining intrashelf basins. The information presented in this paper goes some way to fill this gap in the stratigraphic understanding of the mid-Cretaceous sedimentary system.

\section{Results}

Compelling evidence has been found for major fluvial incisions at the top of the Late Aptian Shu'aiba Formation in Block 5, offshore Qatar (Raven et al., in press). Log correlation, horizontal well results and seismic mapping reveal a major east-west trending, meandering, terraced incised valley running across Block 5, with widely distributed subsidiary valleys. Locally, the main valley reaches $8 \mathrm{~km}$ wide and has a depth of at least $30 \mathrm{~m}$. Additional evidence for exposure of the Shuaiba Formation comes from numerous clay-filled and, occasionally, sand-filled karst fissures that have been encountered at the top of the Shu'aiba Formation, penetrating at least $25 \mathrm{~m}$ below the top surface.

At one location the complete channel-fill was cored and consists of tidally influenced fluvial sandstone deposits, rich in dispersed organic matter, coal and amber, at the base, passing up into tidal estuarine facies and shoreface deposits at the top. The overlying succession consists of a thin sandy interval, rich in glauconite and iron ooids, that blankets the entire Shu'aiba Formation. These deposits are interpreted as a transgressive back-fill systems tract of a major valley system. The overlying glauconitic and iron oolitic sandstones are interpreted as a strongly condensed facies.

The valley-fill sandstones and overlying condensed sheet sandstones are of latest Aptian age and are followed by a stratigraphic hiatus spanning most of the Early Albian. This entire siliciclastic package is interpreted as a latest Aptian depositional sequence that, in both lithological composition and age, is distinct from the overlaying marls and carbonates of the Nahr Umr Formation.

The importance of these observations is that they provide proof for (1) unambiguous subaerial exposure of the the Shu'aiba Formation in Block 5, (2) an Early Late Aptian relative drop in sea level of at least $30 \mathrm{~m}$, (3) a latest Aptian sea level rise of a similar magnitude, and (4) a condensed phase, probably sea level stillstand, during the Early Albian. Since relative sea level fluctuations of this magnitude are likely to have a regional expression, the here established relative sea level curve provides a reference for the Arabian plate.

The palaeogeographical implication of these observations is that the Bab Basin was separated from the siliciclastic sources in the north-west area. Incised river systems providing siliciclastic sediments traversed, however, this paleogeographical barrier in a south-east and northeast (Pink et al., 2008) direction. In addition, the iron-rich, condensed siliciclastic facies show a remarkable lithological resemblance and occur at a stratigraphically comparable position as the 'Burgan Sand' equivalent reported from coastal Fars. This may suggest the presence of a regional condensed stratigraphic interval along a shallow shelf covering at least the cited areas. 


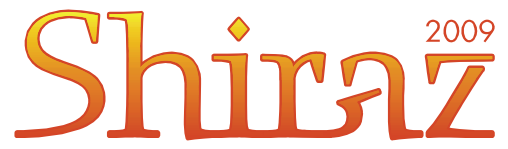

\section{Conclusions}

The following conclusions are drawn:

1. Proof is provided for a significant fall and rise of sea level, with an amplitude in the order of 30 meters, on the arabian plate during the Late Aptian.

2. This sea level fluctuation has significant implications for the facies distribution during the Late Aptian, with notably the karstification and valley incision affecting the exposed carbonate platforms, and the mobilization of siliciciclastics form the hinterland.

3. This reference sea level curve may be used as a guide to study the Late Aptian geological history at other locations on the Arabian plate.

\section{References}

Pink, A., C. Sembritzky, M. Zahranm, 2008, 3D Seismic data helps to lift the Fog - structural and stratigraphic architectural observations from a recent 3D seismic survey, Block 4, Qatar. IPTC 12498.

Raven, M., F. van Buchem, P.-H. Larsen, F. Surlyk, H. Steinhardt, D. Cross, N. Klem, M. Emang (in press) Late Aptian incised valleys and siliciclastic infill at the top of the Shu'aiba Formation (Block 5, offshore Qatar). GeoArabia Special Publication no. 4. 